\title{
Effect of seasonality on chemical profile and antifungal activity of essential oil isolated from leaves Psidium salutare (Kunth) 0. Berg
}

Delmacia G de Macêdo Corresp ${ }^{1}$, Marta Maria A Souza ${ }^{1}$, Maria Flaviana B Morais-Braga ${ }^{1}$ Henrique Douglas Coutinho $^{2}$, Antonia Thassya L dos Santos ${ }^{2}$, Rafael P da Cruz ${ }^{2}$, José Galberto M da Costa ${ }^{2}$, Fábio Fernandes G Rodrigues $^{2}$, Lucindo J Quintans-junior ${ }^{3}$, Jackson Roberto G da Silva Almeida ${ }^{4}$, Irwin Rose A de Menezes ${ }^{\text {Corresp. } 2}$

1 Department of Biological Sciences, Regional University of Cariri, Crato, Ceara, Brazil

2 Department of Biological Chemistry, Regional University of Cariri, Crato, Ceará, Brazil

3 Physiology Department, Federal University of Sergipe, Aracaju, Sergipe, Brazil

${ }^{4}$ Center For Studies and Research of Medicinal Plants, Federal University of San Francisco Valley, Petrolina, Pernambuco, Brazil

Corresponding Authors: Delmacia G de Macêdo, Irwin Rose A de Menezes

Email address: delmaciamacedo@yahoo.com.br, irwin.alencar@urca.br

Medicinal plants play a crucial role in the search for components that are capable of neutralizing the multiple mechanisms of fungal resistance. Psidium salutare (Kunth) 0. Berg is a plant native to Brazil used as both food and traditional medicine to treat diseases and symptoms such as stomach ache and diarrhea, whose symptoms could be related to fungal infections from the genus Candida. The objective of this study was to investigate the influence of seasonal variability on the chemical composition of the Psidium salutare essential oil, its antifungal potential and its effect on the Candida albicans morphogenesis. The essential oils were collected in three different seasonal collection periods and isolated by the hydrodistillation process in a modified Clevenger apparatus with identification of the chemical composition determined by gas chromatography coupled to mass spectrometry (GC/MS). The antifungal assays were performed against Candida strains through the broth microdilution method to determine the minimum fungicidal concentration (MFC). Fungal growth was assessed by optical density reading and the Candida albicans dimorphic effect was evaluated by optical microscopy in microculture chambers. The chemical profile of the essential oils identified 40 substances in the different collection periods with $\gamma$-terpinene being the predominant constituent. The antifungal activity revealed an action against the $C$. albicans, $C$. krusei and $C$. tropicalis strains with an $\mathrm{IC}_{50}$ ranging from 345.5 to $2754.2 \mu \mathrm{g} / \mathrm{mL}$ and a MFC higher than 1024 $\mu \mathrm{g} / \mathrm{mL}$. When combined with essential oils at sub-inhibitory concentrations (MIC/16), fluconazole had its potentiated effect, ie a synergistic effect was observed in the combination of fluconazole with P.salutare oil against all Candida strains, however, for $C$. albicans, its effect was reinforced by the natural product in all the collection periods. The 
results show that the Psidium salutare oil affected the dimorphic transition capacity, significantly reducing the formation of hyphae and pseudohyphae in increasing concentrations. The results show that $P$. salutare oil exhibits a significant antifungal activity against three Candida species and that it can act in synergy with fluconazole would be clearer. These results support the notion that this plant may have a potential use in pharmaceutical and preservative products. 
1 Effect of seasonality on chemical profile and antifungal activity of essential oil isolated from

2 leaves Psidium salutare (Kunth) O. Berg.

3

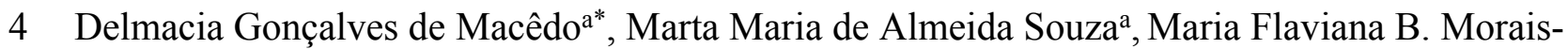

5 Braga $^{\mathrm{a}}$, Henrique Douglas M. Coutinho ${ }^{\mathrm{b}}$, Antonia Thassya L. dos Santos ${ }^{\mathrm{a}}$, Rafael Pereira da

6 Cruz $^{\mathrm{a}}$, José Galberto Martins da Costa ${ }^{\mathrm{b}}$, Fábio Fernandes Galvão Rodrigues ${ }^{\mathrm{b}}$; Lucindo J.

7 Quintans-Júnior ${ }^{c}$; Jackson Roberto Guedes da Silva Almeidad ${ }^{\mathrm{d}}$, Irwin Rose Alencar de Menezes ${ }^{\mathrm{b}^{*}}$

8 a Department of Biological Sciences, Regional University of Cariri, URCA, 63105-000, Crato, 9 CE, Brazil

$10{ }^{b}$ Department of Biological Chemistry, Regional University of Cariri, URCA, 63105-000, Crato, 11 CE, Brazil

$12{ }^{c}$ Physiology Department, Federal University of Sergipe, Sergipe, Brazil.

$13{ }^{d}$ Center For Studies and Research of Medicinal Plants, Federal University of San Francisco 14 Valley, Petrolina, Brazil

16 * Corresponding author at. University of the Region of Cariri, URCA, 63105-000, Crato, CE,

17 Brazil.Tel.: (55) 8899929744.

18 E-mail addresses:delmaciamacedo@yahoo.com.br / irwinalencar@yahoo.com.br 
21 Effect of seasonality on chemical profile and antifungal activity of essential oil isolated from 22 leaves Psidium salutare (Kunth) O. Berg.

Abstract

Medicinal plants play a crucial role in the search for components that are capable of neutralizing the multiple mechanisms of fungal resistance. Psidium salutare (Kunth) O. Berg is a plant native to Brazil used as both food and traditional medicine to treat diseases and symptoms such as stomach ache and diarrhea, whose symptoms could be related to fungal infections from the genus Candida. The objective of this study was to investigate the influence of seasonal variability on the chemical composition of the Psidium salutare essential oil, its antifungal potential and its effect on the Candida albicans morphogenesis. The essential oils were collected in three different seasonal collection periods and isolated by the hydrodistillation process in a modified Clevenger apparatus with identification of the chemical composition determined by gas chromatography coupled to mass spectrometry (GC/MS). The antifungal assays were performed against Candida strains through the broth microdilution method to determine the minimum fungicidal concentration (MFC). Fungal growth was assessed by optical density reading and the Candida albicans dimorphic effect was evaluated by optical microscopy in microculture chambers. The chemical profile of the essential oils identified 40 substances in the different collection periods with $\gamma$-terpinene being the predominant constituent. The antifungal activity revealed an action against the $C$. albicans, $C$. krusei and $C$. tropicalis strains with an $\mathrm{IC}_{50}$ ranging from 345.5 to $2754.2 \mu \mathrm{g} / \mathrm{mL}$ and a MFC higher than $1024 \mu \mathrm{g} / \mathrm{mL}$. When combined with essential oils at sub-inhibitory concentrations (MIC/16), fluconazole had its potentiated effect, ie a synergistic effect was observed in the combination of fluconazole with P.salutare oil against all Candida strains, however, for C. albicans, its effect was reinforced by the natural product in all the collection periods.

The results show that the Psidium salutare oil affected the dimorphic transition capacity, significantly reducing the formation of hyphae and pseudohyphae in increasing concentrations.

48 The results show that $P$. salutare oil exhibits a significant antifungal activity against three 49 Candida species and that it can act in synergy with fluconazole. These results support the notion 
53

54

55

56

57

58

59

60

61

62

63

64

65

66

67

68

69

70

\section{Introduction}

Seasonality variations such as climatic conditions, water restriction, the presence of predators and soil mineral composition may alter secondary plant metabolism (Figueiredo et al., 2008) and, consequently, alter the composition of essential oils throughout the year (Prins, Vieira $\&$ Freitas, 2010). In addition, some specific constituents that present chiral chemical groups are affected by the luminosity rate (Mulas, Gardner \& Craker, 2006). The isolation of plant essential oils is also influenced beyond taxonomic factors, as well as by the variety of epidermal cellular structures that are responsible for the production and storage of essential oils volatile organic compounds (Pinto et al., 2007). Therefore, understanding the seasonal events that alter the quality of the active compounds in the plant is fundamental to support pharmacological studies that contemplate and aim at the formulation of new drugs and direct collection periods in direct commercial plantations of this crop to obtain the oil with greater therapeutic potential.

Many species of the family Myrtaceae have a history of use as traditional medicines in ethnobotanical practices in both tropical and subtropical regions (Souza et al., 2014; Macêdo et al., 2016). Family members comprise the genera Eugenia, Myrcianthes, Campomanesia and Psidium. The Psidium genus has approximately 150 species and can be found in all the tropics and subtropics of America and Australia (Pino et al., 2003) with several therapeutic potentials already described, especially for Psidium guajava Linn. (Gupta, Chahal \& Arora, 2011; Joseph \& Priya, 2011). Antimicrobial activity has been described for several species such as Psidium cattleianum (Faleiro et al., 2016) and Psidium guineense (Fernandes et al., 2012).

Psidium salutare (Kunth) O. Berg., is popularly known in the Northeast region as a "araça preto", often found in Cerrado areas in the Chapada do Araripe, southern Ceará state (Ribeiro-Silva et al., 2012), with five varieties of this species being recognized: var. sericeum, var. mucronatum, var. decussatum and var. pohlianum, which are also found in other countries such as Paraguay, the Caribbean and Mexico (Landrum, 2003). In the Cariri region, in addition to the fruit being edible, the leaves are used in traditional medicine to treat diseases and symptoms such as stomach ache and diarrhea, which may be related to Candida infections (Ribeiro et al., 2014; Souza et al., 2014; Macêdo et al., 2016).

Fungal infections caused by dermatophytes and yeasts of Candida spp., are a serious health problem in immunocompromised patients in particular and are aggravated by the increase 
84 in clinical resistance to the antifungal agents (Silva et al., 2012; Morais-Braga et al., 2016b). In

85 view of this problem, the interest in the use of vegetable derivatives with therapeutic potential for

86

87 88 antifungal action has intensified (Macêdo et al., 2015). These new substances of plant origin may represent alternative and less toxic treatments for the treatment of infections (Vandeputte, Ferrari \& Coste, 2011), synergism and inhibition of germ tube formation by compounds derived from Crocus sativus against Candida spp (Carradori et al., 2016). Considering the medicinal importance of the genus Psidium and the absence of studies with Psidium salutare, this is the first study to describe the chemical profile of $P$. salutare leaf essential oil, and the influence of seasonal variation on its composition, antifungal activity and potency to inhibit the morphogenetic switch in Candida species.

\section{Materials and Methods}

\subsection{Collection area of botanical material}

Psidum salutare leaves were collected in an area of Cerrado sensu stricto, at Fazenda Barreiro Grande (latitude: $7^{\circ} 21^{\prime} 41.7^{\prime \prime} \mathrm{S}$ and longitude 39 $28^{\prime} 42.4^{\prime \prime} \mathrm{W}$, altitude of $909 \mathrm{~m}$ above sea level), located in the Chapada do Araripe, Ceará, Northeast of Brazil, presenting altitudes varying between 870 and 970 meters. The region receives on average of $1.043 \mathrm{~mm}(\mathrm{~mm})$ of rainfall per year (FUNCEME, 2016), where they concentrate between January and May with a dry period that lasts between five and seven months, with a critical shortage between July and September (Table 1). According to the Köppen classification system, the climate is hot humid Tropical (Aw) with an average annual of temperature between 24 and $26^{\circ} \mathrm{C}$. The collection is under the authorization of the competent ICMBio with number $\left(\mathrm{n}^{\circ} .50362-2\right)$.

\subsection{Plant material}

Fresh leaves of the species Psidum salutare were collected in the months of February, May and August in different periods, dry and rainy season, to evaluate the antifungal activity and the chemical compounds, as described in Table 1, between 8:30 am and 9:30 am. They were then transported to Laboratory of Ecology of Plants of the Regional University of Cariri - URCA. 
115 Species exsiccates were produced, identified by Dr. Marcos Sobral (specialist in the Myrtaceae

116 family) and deposited in the Heririum of Caririense Dárdano de Andrade-Lima of the Regional

117 University of Cariri - URCA under number 12601 HCDAL.

118

119

\subsection{Obtaining and analyzing the essential oil}

120

121

122

Approximately $500 \mathrm{~g}$ of fresh leaves collected were selected, washed, crushed and submitted to the hydrodistillation process for two hours in a Clevenger type apparatus. The essential oil was then dehydrated with anhydrous sodium sulfate $\left(\mathrm{Na}_{2} \mathrm{SO}_{4}\right)$ and kept in an amber flask under refrigeration $<4^{\circ} \mathrm{C}$ until analyzed. The yields were determinate by volume/weight on dry weight basis.

Analysis of the oil was performed using a Shimadzu GC-17 A/MSQP5050A (GC/MS system): DB-5HT capillary column (30 m x $0.251 \mathrm{~mm}, 0.1 \mathrm{~mm}$ of thickness); helium carrier gas at $1.7 \mathrm{~mL} / \mathrm{min}$; injection temperature $270{ }^{\circ} \mathrm{C}$; detector temperature $290{ }^{\circ} \mathrm{C}$; column temperature $60{ }^{\circ} \mathrm{C}(2 \mathrm{~min})-180{ }^{\circ} \mathrm{C}(1 \mathrm{~min})$ at $4{ }^{\circ} \mathrm{C} / \mathrm{min}$, then $180-260{ }^{\circ} \mathrm{C}$ at $10{ }^{\circ} \mathrm{C} / \mathrm{min}(10 \mathrm{~min})$. The reading speed was $0.5 \mathrm{scan} / \mathrm{s}$ of $\mathrm{m} / \mathrm{z} 40-450$ with a split ratio of 1:30. The injection volume was $1 \mu \mathrm{L}$ of $5 \mathrm{mg} / \mathrm{mL}$ of ethyl acetate solution. Avoid dead time $=3 \mathrm{~min}$. The mass spectrometer was operated with ionization energy of $70 \mathrm{eV}$. The identification of the components was by comparison of their respective mass spectrum standards with those registered in the database of Wiley Online Library (229) and with the calculated retention indices with values of literature (McLafferty \& Stauffer, 1994; Adams, 2007).

136

\subsection{Antifungal activity evaluation}

138

\subsubsection{Culture media and inocula}

For the antifungal activity assays, three standard strains of yeast fungi of the genus

142 Candida were used: C. albicans - CA INCQS 40006, C. tropicalis - CT INCQS 40042 and C.

143 krusei - CK INCQS 40095, obtained from the Oswald Cruz Cultures Collection of the National

144 Institute of Quality Control in Health (INCQS). All strains were grown on Sabouraud Dextrose 145 agar (SDA-KASVI) and incubated at $37^{\circ} \mathrm{C}$ for $24 \mathrm{~h}$. From these, suspensions of the 
146 microorganisms were prepared in tubes containing $3 \mathrm{ml}$ of sterile solution $(0.9 \% \mathrm{NaCl})$. The

147 inoculum concentration was standardized according to the McFarland scale, comparing inoculum

148 turbidity with the 0.5 standard on the scale equivalent to $10^{5} / 10^{6}$ cells per $\mathrm{mL}$. The potato

149 dextrose agar (PDA, DIFCO) was prepared by diluting it more than that recommended by the

150 manufacturer to make it a depleted medium capable of stimulating yeast to produce hyphae.

151 Agar was added to this diluted medium to obtain a solid medium.

152

153

2.3.2 Determination of the Inhibitory Concentration of $50 \%$ of the microorganisms $\left(I C_{50}\right)$ and

obtaining the cellular viability curve

155

156

The different $P$. salutare essential oil samples from the periodic collections in the rainy 157 and dry seasons were tested for their antifungal activity. Both the essential oil and antifungal fluconazole (from Sigma - F8929 $\geq 98 \%$ (HPLC), powder) was previously diluted in dimethylsulfoxide (DMSO - Dynamic) and its final concentration was adjusted with addition of distilled water to obtain the desired concentration for $(16384 \mu \mathrm{g} / \mathrm{ml})$. The oil and fluconazole solutions were posteriorly microdiluted in Sabouraud Dextrose Broth (SDB) medium in a serial concentration manner ranging from 8192 to $8 \mu \mathrm{g} / \mathrm{mL}$ in 96 -well plates. The penultimate well, the latter serving as a growth control (Javadpour et al., 1996). The concentration of DMSO at the oil concentrations ranged from 5 to $0.004 \%$. Product dilutions (using saline instead of inoculum) and medium sterility controls were also achieved. The plates were then taken to an incubation chamber for 24 hours at $37{ }^{\circ} \mathrm{C}$ and following this period the plates were read using an ELISA spectrophotometer (Thermoplate ${ }^{\circledR}$ ) apparatus. The results obtained in the ELISA reading were used to construct the cell viability curve and to determine the $\mathrm{IC}_{50}$ of the $P$. salutare essential oils (Morais- Braga et al., 2016 b). All test were perfomed in triplicate.

\subsubsection{Determination of the minimal fungicidal concentration (MFC)}

173

A small sterile rod was placed in each well of the microdilution test plate, with the exception of the sterility control. After mixing the medium in each well, the rod was taken to a large petri dish containing SDA, where by touching the surface, the solution (medium + 
177 inoculum + natural product) was transferred for yeast subculture and cell viability analysis. The

178 plates were incubated at $37{ }^{\circ} \mathrm{C}$ for 24 hours, and checked for the growth or non-growth of

179 Candida colonies (Ernst et al., 1999). The concentration at which there was no growth of fungal

180 colonies was considered the MFC of the natural product.

181

1822.4 Evaluation of the Psidium salutare essential oil modulating effect on the antifungal activity 183 offluconazole

184

185

186

187

188

189

190

191

192

193

The solution containing the essential oil of $P$. salutare (OEFPs) was tested in subinhibitory concentration (MFC/16). The volume of $100 \mu \mathrm{L}$ of a solution containing SDB (Sabouraud Dextrose Broth), 10\% inoculum and natural product were distributed in each well in the alphabetical direction of the plate. Afterwards, $100 \mu \mathrm{L}$ of the antifungal were mixed to the first well and serially microdiluted in a ratio of $1: 1$, the latter cavity being used as fungus growth control (Coutinho et al., 2008). The fluconazole concentrations varied gradually from 8192 to 8 $\mu \mathrm{g} / \mathrm{mL}$. Dilution controls of the natural products (OEFPs) were used where the inoculum was replaced by saline/DMSO and control of sterility with the medium. The plates were incubated at $37^{\circ} \mathrm{C}$ for 24 hours and reading was done on a spectrophotometer, Thermoplate ${ }^{\circledR}$ ELISA, with a wavelength of $630 \mathrm{~nm}$ (Morais- Braga et al., 2016 b).

195

\subsection{Effect of the Psidium salutare leaf oil on Candida albicans morphogenesis}

The essential oil from the three samples collected at different periods were used to observe if the natural product caused any alteration in the morphogenesis of $C$. albicans, the oil was tested in different concentrations such as the Superior Evaluated Concentration - SEC (8,192 $\mu \mathrm{g} / \mathrm{mL}), \mathrm{SEC} / 4(2,048 \mu \mathrm{g} / \mathrm{mL})$ and SEC/16 $(512 \mu \mathrm{g} / \mathrm{mL})$.

The trials were performed with some modifications according to Sidrim and Rocha (2010) and Mendes (2011). The medium (3 mL) were combined to the tested product, were by the agitator. After solidification of the medium, the yeast was seeded with the aid of a $1 \mu \mathrm{L}$ calibrated loop and two parallel grooves were extracted. The striae were covered with sterile 
208

209

210

211

212

213

214

215

216

217

218

219

220

221

222

223

224

225

226

227

228

229

230

231

232

233

234

235

236

237

238

40x objective optical microscope. A control for yeast growth (hyphae stimulated by depleting medium) was performed, as well as a control with the conventional antifungal fluconazole for comparative purposes. Tests using DMSO as a control were previously performed (Morais-Braga et al., 2016a), demonstrating that it does not cause inhibition of hyphae at the concentrations tested.

\subsection{Statistical analysis}

The data obtained for each sample were checked for their normal distribution and then analyzed by One-Way ANOVA followed by Tukey's test. The $\mathrm{IC}_{50}$ values were computed by linear regression for interpolation in standard curves relating the percentage (\%) growth values and the concentration of the product in $\mu \mathrm{g} / \mathrm{mL}$ using the GraphPad Prism software, version 6.0. All analyzes were performed in triplicates (see raw data in supplementary data attached).

\section{Results}

In the evaluation of the yield of the essential oil Psidium salutare in the analyzed periods, February (0.73\%), May (0.29\%) and August (0.15\%) show that highest yields coincident with the precipitation periods and dryness in the region, however, it was not possible to obtain a statistically significant correlation. Then, when analyzing the Psidium salutare oil yield, the beginning of the rainy season was the ideal period for collection. In the $P$. salutare GC/MS analysis it was possible to identify an average of $89.13 \%$ of the constituents corresponding to 40 compounds (Table 2). When calculating the average of the compounds, a predominance of monoterpene hydrocarbons (39.79\%), sesquiterpene hydrocarbons (20.94\%), oxygenated monoterpenes (12.98\%) and oxygenated sesquiterpenes (14.91\%) can be observed.

The major constituents were linalool, p-Cymene, terpinolene, $\gamma$-terpinene and $\tau$-cadinol. The results obtained during the collection periods showed that although several compounds presented a random composition, others remained constant. In the rainy season in February and May, the compounds that stood out were terpinolene $(14.49$ - 16.99\%), $\gamma$-terpinene (13.97 $17.09 \%)$, $\tau$-cadinol (12.75-10.51\%), p-Cymene (5.05-6.37\%) and linalool (5.55-4.72\%). In the dry season, represented by August, the major compounds were p-cymene (17.83\%), $\gamma$-terpinene 
239 (10.32\%), $\tau$-cadinol (10.35\%) and linalool (7.26\%). In the dry season, represented by August, the 240 major compounds were p-cymene (17.83\%), $\gamma$-terpinene $(10.32 \%), \tau$-cadinol $(10.35 \%)$ and 241 linalool (7.26\%). This variation can be partly explained by the fact that environmental factors 242 can affect certain chemical compounds while exerting any influence on the production of other 243 chemicals.

244 The intrinsic $P$. salutare essential oil antifungal activity at different collection times, 245 against different Candida strains showed no significant clinical activity (MIC $\geq 1024 \mu \mathrm{g} / \mathrm{mL}$ ), 246 demonstrating that it was little influenced by changes in the chemical composition of the oil and 247 by rainfall (Table 3). In this sense, although punctually significant, the chemical variations in the 248 oil composition were not able to exhibit satisfactory inhibitory effect against Candida strains 249 showing effects only in high concentrations, Candida albicans INCQS 40006 (4096 $\mu \mathrm{g} / \mathrm{mL})$, 250 Candida tropicalis INCQS $40042(\geq 16,384 \mu \mathrm{g} / \mathrm{ml})$ and Candida krusei INCQS 40095 (1024 $251 \mu \mathrm{g} / \mathrm{ml})$ (Table 3).

252 Among the analyzed periods, the $\mathrm{IC}_{50}$ (Ability to Inhibit 50\% of cells), of products ranged 253 from 345.5 to $2754.2 \mu \mathrm{g} / \mathrm{mL}$ and image of the cellular viability curve in different concentrations 254 of essential oil, the lowest value recorded for $C$. albicans was related to the first collection 255 period, with an $\mathrm{IC}_{50}$ of $581.3 \mu \mathrm{g} / \mathrm{mL}$ (Figure 1A), precipitation of $49 \mathrm{~mm}$ and elevated major 256 compounds, such as terpinolene, $\tau$-cadinol and $\gamma$-terpinene. For $C$. tropicalis, the lowest $\mathrm{IC}_{50}$ 257 value was observed in the last collection period $(1621.8 \mu \mathrm{g} / \mathrm{mL}$ ) (Figure 1C), coinciding with the 258 dry period in the region, with p-cymene, linalol, $\gamma$-terpinene and $\tau$-cadinol in higher 259 concentrations in the sample.

260 However, for C. krusei the antifungal activity was showed more active in second 261 collection period $(345.5 \mu \mathrm{g} / \mathrm{mL}$ ) (Figure 1E) with significant value when compared to 262 fluconazole $\mathrm{IC}_{50}$ of $271.3 \mu \mathrm{g} / \mathrm{mL}$ (Table 4). This result corroborates with an incidence of 263 precipitation of $145 \mathrm{~mm}$ and presence of the major $\gamma$-terpinene, $\tau$-cadinol and terpinolene 264 compounds in the sample.

265 For the Intrinsic Minimal Fungicide Concentration (MFC) the results showed a chemical 266 variation in the essential oil composition between dry and rainy periods, thus influencing the 267 concentration for $C$. albicans $(4096 \mu \mathrm{g} / \mathrm{mL})$ and $C$. krusei $(1024 \mu \mathrm{g} / \mathrm{mL})$, however for $C$. 268 tropicalis $(\geq 16,384 \mu \mathrm{g} / \mathrm{mL})$ the concentrations remained constant. 
In the verification of the potential modifier of the effect of fluconazole by the essential oil 270 (Table 4), we can verify that there was a modulatory activity for all strains (Figure $1 \mathrm{~B}, \mathrm{D}, \mathrm{F}$ ), 271 especially for C. albicans 40006 (2.7 to $8.0 \mu \mathrm{g} / \mathrm{mL})$, which exhibited lower concentrations than 272 when compared to fluconazole alone ( $\left.\mathrm{IC}_{50} 16.7 \mu \mathrm{g} / \mathrm{mL}\right)$, exhibiting synergism in all curves at all 273 collection periods analyzed, promoting an inhibitory effect on microorganisms, greater than sum 274 of the effects of individuals.

275 The effect of the natural product on morphological transition in C. albicans was evaluated 276 by microcultive assay. It can be observed that the essential oil inhibited the formation of hyphae 277 and pseudohyphae at concentrations starting from $512.0 \mu \mathrm{g} / \mathrm{mL}$, resulting in the reduction of

278 fungal virulence (Figure 2). The microscopy results shown in Figure 2 demonstrate that the 279 essential oil can inhibit germinative tube formation and reduce hyphae elongation, which can be 280 considered effective against $C$. albicans dimorphism, thus reducing fungal progression and the 281 spread of infection.

282

283

\section{Discussion}

284

As expected, the chemical composition varied during the analyzed period. This result 286 corroborates with other studies that have shown that environmental factors can affect certain chemical compounds, while in others they have no influence on their production (Araujo et al., 2010; Estell et al., 2016). In the leaves of Camellia sinensis, the main catechins (epigallocatechin gallate, epicatechin) varied during the year, and this variation was associated to the following environmental factors that can act in combination or alone: day length, sunlight and / or temperature (Yao et al. al., 2005). According to studies the rainy season was favorable for the production of Copaifera langsdorffii Desff oils (Souza de Oliveira et al., 2017), Eucalyptus citriodora Hook (Castro et al., 2008) and Cymbopogon citratus (Santos et al., 2009).

In the present study, the production of the major compounds such as Terpinolene and $\gamma$ terpinene in the milder months $\left(26^{\circ} \mathrm{C}\right)$ was positively influenced, with an increase in the positively influenced in the warmer period, which shows that similar compounds can be altered 
298 simultaneously by the same factor, resulting in variations throughout the year, except for the $\tau$ 299 cadinol compound that remained stable.

300 Comparing the results with available literature, the rainy season was also favorable for 301 the yield of oils Copaifera langsdorffii Desff (Souza de Oliveira et al., 2017), Eucalyptus 302 citriodora Hook (Castro et al., 2008) and Cymbopogon citratus (Santos et al., 2009). The 303 presence of the major compounds as, $\gamma$-terpinene, terpinolene, $\tau$-cadinol, $\mathrm{p}$-cymene and linalool 304 in the essential oil of the species under study, were also present in P. myrsinites Mart. (Medeiros 305 et al., 2015), Psidium pohlianum O. Berg, Psidium guyanensis Pers (Neto et al., 1994) and 306 Psidium caudatum McVaugh (Yáñez et al., 2002).

Variations in plant active components are important parameters to correlate biological 308 activity, including antibacterial, antifungal and insecticide. Knowledge of the abiotic factors 309 influencing the chemical variability and essential oil yield is important for optimizing crop conditions and harvesting time so that they are of high quality, factors essential for commercialization. In addition, a number of biotic factors such as plant/micro-organism

312 (Stoppacher et al., 2010), plant/insects (Kessler \& Baldwin, 2001) and plant/plant interactions,

313 age and development stage, as well as abiotic factors such as luminosity (Takshak \& Agrawal, 314 2016), temperature, rainfall, nutrition, time and harvest time (Bitu et al., 2015), may present 315 correlations with each other, acting in conjunction, and may exert a joint influence on the 316 chemical variability and essential oil yield.

317 The major compounds terpinolene, $\tau$-cadinol and $y$-terpinene, have already been reported 318 in other plants that have been studied for their antifungal activity against $C$. albicans (Tampieri 319 et al., 2005), however, none of the compounds were studied to evaluate their activity against $C$. 320 krusei. Moreover, studies with C. tropicalis verify that the compounds p-cymene and linalool 321 also possess an inhibitory effect (Hsu et al., 2013; de Oliveira Lima et al., 2017).

Combination therapy using natural and antimicrobial products has been reported as an 323 important strategy to combat the development of microbial resistance due to the production of an 324 additive or synergistic effect. Thus, we demonstrated that the essential oil association with 325 fluconazole may represent a therapeutic benefit in reducing the antifungal dosage, representing 326 an improvement in toxic levels, while producing a fungicidal effect (Pemmaraju et al., 2013).

This is the first work that shows the potential modulating activity of $P$. salutare essential 328 oil, so there was no way to compare the results here with respect to the species. Within the genus 
329 Psidium, some data exist, however, they are related to extracts. Morais-Braga et al. (2016)

330 observed fluconazole and all extracts had high inhibitor concentrations, however, when these

331 were in association with sub-inhibitory concentrations (MIC/16), fluconazole had an improved

332 effect, thus a synergistic effect was observed in the combination of fluconazole with extracts of

333 Psidium brownianum against all strains of Candida (Morais-Braga et al., 2016b). According to

334 this study, Castro et al. (2015) demonstrated that the Psidium cattleianum essential oil had an

335 effect on the inhibition of important clinical fungal strains such as Trichosporon asahii (Castro et

336 al., 2015), Candida parapsilosis, Candida albicans, Candida lipolytica and Candida

337 guilhermondi, with concentrations ranging from $41.67 \pm 18.04$ to $16,670 \pm 72.17 \mu \mathrm{g} / \mathrm{mL}$ for the 338 tested strains.

339 The C. albicans was selected for association study, because, it is the most common 340 pathogenic agent involved in systemic infections and the main strain responsible for infections 341 caused by Candida fungi (Romani, 2012; Yapar, 2014). In previous studies, of our research 342 group, with other species of this genus, P. brownianum and P. guajava extracts had their 343 antifungal potential investigated, obtaining favorable results, where they also managed to affect 344 the phenotypic plasticity of C. albicans and C. tropicalis, reducing the formation process of 345 hyphae and pseudohyphae as their concentrations were increased (Morais-Braga et al., 2016b,a, 346 2017).

Candida albicans is a polymorphic fungus that can grow both in the yeast form (ovoid 348 form), elongated ellipsoid cells with constrictions in the septa (pseudohyphae), or as true hyphae 349 of parallel walls, as can be observed in Figure 2 - Growth Control (Berman, 2002). The hyphae 350 or pseudohyphae forms are responsible for the infectious process ranging from superficial skin 351 infections to life-threatening systemic infections. Transition to the hyphae form can be triggered 352 by increases in temperature to $37^{\circ} \mathrm{C}$, increases in $\mathrm{pH}$, and the addition of inducers (Shareck and 353 Belhumeur, 2011). In this form, the germinating tube and the tip extension can generate strong 354 pressures for tissue penetration due to the secretion of proteases, lipases and other histological 355 enzymes. This is important since hyphae formation is central to another aspect of Candida's 356 virulence: development of biofilms that is associated with increased resistance to antifungal 357 medications (Calderone \& Fonzi, 2001). 
Some authors have proposed that the essential oil activity may be in part related to its

359

360

361

362

363

364

365

366

367

368

369

370

371

372

373

374

375

376

377

378

379

380

381

382

383

384

385

hydrophobicity, responsible for its partition of the cell membrane lipid bilayer, leading to a change in permeability and cell membrane damage resulting from direct damage to the membrane resulting in a reduced ability to maintain cellular functions (Braga et al., 2007; Hsu et al., 2013). Another mechanism is related to a metabolic impairment with a reduction of 3 ':5'"cyclic adenosine monophosphate (cAMP) formation and, together with a mitogenic activation protein (MAP) signaling pathway, responsible for playing an important role in the formation of filamentous forms (Hollosy \& Keri, 2004; Deveau et al., 2010; Dižová \& Bujdáková, 2017). Several mechanisms have been tested in order to provide new and valuable means to combat Candida pathogenesis that may lead to new strategies for the development of antifungal drugs.

\section{Conclusion}

In conclusion, the essential oil of P.salutare presented as main components, hydrogenated monoterpenes, as $\gamma$-terpinene, whose composition was influenced by the beginning of the rainy season, proving to be the ideal period for the isolation of oil. It is not possible to affirm that the antifungal activity of the oil was influenced by the seasonal changes in the precipitation, with the exception of C. krusei, where it presented the lower MFC and $\mathrm{IC}_{50}$ values. The essential oil demonstrated a significant effect on Candida morphogenesis, reducing the ability of morphological transitions from invasive infectious processes and resistance to $C$. albicans. In this way, the presented results can be a starting point for new in vivo assays for the possible development of new complementary and alternative therapies, as well as to support its popular medicinal use against diseases of fungal origin.

\section{Acknowledgments}

The authors acknowledge the support and cooperation received from LEV/LPPN/ LMBM (Laboratory of plant ecology/ Laboratory of Natural Products Research / Microbiology and Molecular Biology Laboratory). 
386

387

388

389

390

391

392

393

394

395

396

397

398

399

400

401

402

403

404

405

406

407

408

409

410

411

412

413

414

415

416

417

418

419

420

421

422

\section{References}

Adams RP. 2007. Identification of essential oil components by gas chromatography/mass spectrometry. Allured publishing corporation.

Bitu V., da Costa J., Rogrigues F., Colares A., Coutinho H., Botelho M., Portela A., de Santana N., Menezes I. 2015. Effect of collection time on composition of essential oil of LippiagracilisSchauer(Verbenaceae)growing in Northeast Brazil. Journal of Essential Oil Bearing Plants. DOI: 10.1080/0972060X.2014.935043.

Braga PC., Alfieri M., Culici M., Dal Sasso M. 2007. Inhibitory activity of thymol against the formation and viability of Candida albicans hyphae. Mycoses 50:502-506.

Calderone RA., Fonzi WA. 2001. Virulence factors of Candida albicans. Trends in microbiology 9:327-335.

Castro NEA., Carvalho GJ., Cardoso MG., Pimentel FA., Correa RM., Guimarães LGL. 2008. Avaliação de rendimento e dos constituintes químicos do óleo essencial de folhas de Eucalyptus citriodora Hook. colhidas em diferentes épocas do ano em municípios de Minas Gerais. Rev. Bras. Pl. Méd 10:70-75.

Castro MR., Victoria FN., Oliveira DH., Jacob RG., Savegnago L., Alves D. 2015. Essential oil of Psidium cattleianum leaves: Antioxidant and antifungal activity. Pharmaceutical biology $53: 242-250$.

Coutinho HDM., Costa JGM., Lima EO., Falcão-Silva VS., Siqueira-Júnior JP. 2008. Enhancement of the antibiotic activity against a multiresistant Escherichia coli by Mentha arvensis L. and chlorpromazine. Chemotherapy 54:328-330.

Deveau A., Piispanen AE., Jackson AA., Hogan DA. 2010. Farnesol induces hydrogen peroxide resistance in Candida albicans yeast by inhibiting the Ras-cyclic AMP signaling pathway. Eukaryotic cell 9:569-577.

Dižová S., Bujdáková H. 2017. Properties and role of the quorum sensing molecule farnesol in relation to the yeast Candida albicans. Die Pharmazie-An International Journal of Pharmaceutical Sciences 72:307-312.

Ernst EJ., Klepser ME., Ernst ME., Messer SA., Pfaller MA. 1999. In vitro pharmacodynamic properties of MK-0991 determined by time-kill methods. Diagnostic microbiology and infectious disease 33:75-80.

Faleiro JH., Gonçalves RC., dos Santos MNG., da Silva DP., Naves PLF., Malafaia G. 2016. The chemical featuring, toxicity, and antimicrobial activity of Psidium cattleianum (Myrtaceae) Leaves. New Journal of Science 2016.

Fernandes TG., de Mesquita ARC., Randau KP., Franchitti AA., Ximenes EA. 2012. In vitro synergistic effect of Psidium guineense (Swartz) in combination with antimicrobial agents against methicillin-resistant Staphylococcus aureus strains. The Scientific World Journal 2012. 
423

424

425

426

427

428

429

430

431

432

433

434

435

436

437

438

439

440

441

442

443

444

445

446

447

448

449

450

451

452

453

454

455

456

457

458

459

460

Figueiredo AC., Barroso JG., Pedro LG., Scheffer JJC. 2008. Factors affecting secondary metabolite production in plants: volatile components and essential oils. Flavour and Fragrance journal 23:213-226.

Gupta GK., Chahal J., Arora D. 2011. Psidium guajava Linn.: Current research and future prospects. J Pharm Res 4:42-46.

Hollosy F., Keri G. 2004. Plant-derived protein tyrosine kinase inhibitors as anticancer agents. Current Medicinal Chemistry-Anti-Cancer Agents 4:173-197.

Hsu C-C., Lai W-L., Chuang K-C., Lee M-H., Tsai Y-C. 2013. The inhibitory activity of linalool against the filamentous growth and biofilm formation in Candida albicans. Medical mycology 51:473-482.

Javadpour MM., Juban MM., Lo W-CJ., Bishop SM., Alberty JB., Cowell SM., Becker CL., McLaughlin ML. 1996. De novo antimicrobial peptides with low mammalian cell toxicity. Journal of medicinal chemistry 39:3107-3113.

Joseph B., Priya RM. 2011. Phytochemical and biopharmaceutical aspects of Psidium guajava (L.) essential oil: a review. Res J Med Plant 5:432-442.

Kessler A., Baldwin IT. 2001. Defensive function of herbivore-induced plant volatile emissions in nature. Science 291:2141-2144.

Landrum LR. 2003. A revision of the Psidium salutare complex (Myrtaceae). SIDA, Contributions to Botany:1449-1469.

Macêdo DG., Menezes IRA., Lacerda SR., da Silva MAP., Ribeiro DA., Macêdo MS., Oliveira LGS., Saraiva ME., Alencar SR., Oliveira SF., Santos MO., de Almeida B V., Macedo JGF., Sousa FFS., Soares MA., de Araujo TMS., Souza MMA. 2016. Versatility and consensus of the use of medicinal plants in an area of cerrado in the Chapada do Araripe, Barbalha - CE- Brazil. Journal of Medicinal Plants Research 10:505-514. DOI: 10.5897/JMPR2015.5952.

Macêdo DG., Ribeiro DA., Coutinho HDM., Menezes IRA., Souza MMA. 2015. Therapeutic traditional practices: Usage and knowledge of cerrado plants in the State of Pernambuco (Northeastern Brazil). Boletin Latinoamericano y del Caribe de Plantas Medicinales y Aromaticas 14.

McLafferty FW., Stauffer DB. 1994. Wiley registry of mass spectral data. Mass Spectrometry Library Search System Bench-Top/PBM, version 3.

Medeiros FCM de., Del Menezzi CHS., Bizzo HR., Vieira RF. 2015. Scents from Brazilian Cerrado: Psidium myrsinites DC.(Myrtaceae) leaves and inflorescences essential oil. Journal of Essential Oil Research 27:289-292.

Morais-Braga MFB., Carneiro JNP., Machado AJT., Sales DL., Brito DIV., Albuquerque RS., Boligon AA., Athayde ML., Calixto Júnior JT., Souza DSL., Lima EO., Menezes IRA., Costa JGM., Ferreira FS., Coutinho HDM. 2016a. High-Performance Liquid Chromatography-Diodic Array Detector, Fungistatic, and Anti-Morphogenical Analysis of 
461

462

463

464

465

466

467

468

469

470

471

472

473

474

475

476

477

478

479

480

481

482

483

484

485

486

487

488

489

490

491

492

493

494

495

496

497

498

Extracts from Psidium brownianum Mart. ex DC. Against Yeasts of the Genus Candida. International Journal of Food Properties 19:1837-1851. DOI: 10.1080/10942912.2015.1079786.

Morais-Braga MFB., Carneiro JNP., Machado AJT., Sales DL., dos Santos ATL., Boligon AA., Athayde ML., Menezes IRA., Souza DSL., Costa JGM., Coutinho HDM. 2017. Phenolic composition and medicinal usage of Psidium guajava Linn.: Antifungal activity or inhibition of virulence? Saudi Journal of Biological Sciences 24. DOI: 10.1016/j.sjbs.2015.09.028.

Morais-Braga MFB., Sales DL., Carneiro JNP., Machado AJT., dos Santos ATL., de Freitas MA., Martins GMDAB., Leite NF., de Matos YMLS., Tintino SR., Souza DSL., Menezes IRA., Ribeiro-Filho J., Costa JGM., Coutinho HDM. 2016b. Psidium guajava L. and Psidium brownianum Mart ex DC.: Chemical composition and anti - Candida effect in association with fluconazole. Microbial Pathogenesis 95:200-207. DOI: 10.1016/j.micpath.2016.04.013.

Mulas G., Gardner Z., Craker LE. 2006. Effect of light quality on growth and essential oil composition in rosemary. In: I International Symposium on the Labiatae: Advances in Production, Biotechnology and Utilisation 723. 427-432.

Neto MA., de Alencar JW., Cunha AN., Silveira ER., Batista TG. 1994. Volatile Constituents of Psidium pohlianum Berg, and Psidium guyanensis Pers. Journal of Essential Oil Research 6:299-300.

de Oliveira Lima MI., de Medeiros ACA., Silva KVS., Cardoso GN., de Oliveira Lima E., de Oliveira Pereira F. 2017. Investigation of the antifungal potential of linalool against clinical isolates of fluconazole resistant Trichophyton rubrum. Journal de mycologie medicale 27:195-202.

Pemmaraju SC., Pruthi PA., Prasad R., Pruthi V. 2013. Candida albicans biofilm inhibition by synergistic action of terpenes and fluconazole.

Pino JA., Bello A., Urquiola A., Agüero J. 2003. Leaf oil of Psidium salutare (HBK) Berg. from Cuba. Journal of Essential Oil Research 15:19-20.

Pinto JEBP., Cardoso JCW., de Castro EM., Bertolucci SK V., de Melo LA., Dousseau S. 2007. Morphophysiological aspects and essential oil content in Brazilian-lavender as affected by shadowing. Horticultura Brasileira 25:210-214.

Prins CL., Vieira IJC., Freitas SP. 2010. Growth regulators and essential oil production. Brazilian Journal of Plant Physiology 22:91-102.

Ribeiro-Silva S., de Medeiros MB., Gomes BM., Seixas ENC., da Silva MAP. 2012. Angiosperms from the Araripe national forest, Ceará, brazil. Check List 8:744-751.

Ribeiro DA., Oliveira LGS De., Macêdo DG De., Menezes IRA De., Costa JGM Da., Silva MAP Da., Lacerda SR., Souza MMDA. 2014. Promising medicinal plants for bioprospection in a Cerrado area of Chapada do Araripe, Northeastern Brazil. Journal of Ethnopharmacology 
500 Romani L. 2012. Immunology of invasive candidiasis. In: Candida and Candidiasis, Second Edition. American Society of Microbiology, 127-136.

502 Santos A., Paduan RH., Gazin ZC., Jacomassi E., D’Oliveira PS., Cortez DAG., Cortez LER.

503

504

505

506

507

508

509

510

511

512

513

514

515

516

517

518

519

520

521

522

523

524

525

526

527

528

529

530

531

532

533 2009. Determinação do rendimento e atividade antimicrobiana do óleo essencial de Cymbopogon citratus (DC.) Stapf em função de sazonalidade e consorciamento. Rev Bras Farmacogn 19:436-441.

Silva S., Negri M., Henriques M., Oliveira R., Williams DW., Azeredo J. 2012. Candida glabrata, Candida parapsilosis and Candida tropicalis: biology, epidemiology, pathogenicity and antifungal resistance. FEMS microbiology reviews 36:288-305.

Souza de Oliveira LG., Alves Ribeiro D., Eufrasio Saraiva M., Gonçalves de Macêdo D., Gonçalves Ferreira Macedo J., Gonçalves Pinheiro P., Martins da Costa JG., de Almeida Souza MM., Alencar de Menezes IR. 2017. Chemical variability of essential oils of Copaifera langsdorffii Desf. in different phenological phases on a savannah in the Northeast, Ceará, Brazil. Industrial Crops and Products 97. DOI: 10.1016/j.indcrop.2016.12.031.

Souza RKD., da Silva MAP., de Menezes IRA., Ribeiro DA., Bezerra LR., Souza MM de A., da Silva MAP., de Menezes IRA., Ribeiro DA., Bezerra LR., Souza MM de A. 2014. Ethnopharmacology of medicinal plants of carrasco, northeastern Brazil. Journal of Ethnopharmacology 157:99-104. DOI: 10.1016/j.jep.2014.09.001.

Stoppacher N., Kluger B., Zeilinger S., Krska R., Schuhmacher R. 2010. Identification and profiling of volatile metabolites of the biocontrol fungus Trichoderma atroviride by HSSPME-GC-MS. Journal of Microbiological Methods 81:187-193.

Takshak S., Agrawal SB. 2016. The role of supplemental ultraviolet-B radiation in altering the metabolite profile, essential oil content and composition, and free radical scavenging activities of Coleus forskohlii, an indigenous medicinal plant. Environmental Science and Pollution Research 23:7324-7337.

Tampieri MP., Galuppi R., Macchioni F., Carelle MS., Falcioni L., Cioni PL., Morelli I. 2005. The inhibition of Candida albicans by selected essential oils and their major components. Mycopathologia 159:339-345.

Yáñez X., Pinzón ML., Solano F., Sánchez LR. 2002. Chemical composition of the essential oil of Psidium caudatum McVaugh. Molecules 7:712-716.

Yapar N. 2014. Epidemiology and risk factors for invasive candidiasis. Therapeutics and clinical risk management 10:95. 


\section{Table $\mathbf{1}$ (on next page)}

The average annual of meteorological conditions for each collection (2016)

OEFPs: Essential Oil of Psidium salutare sheets, 1, 2, 3 collection. 


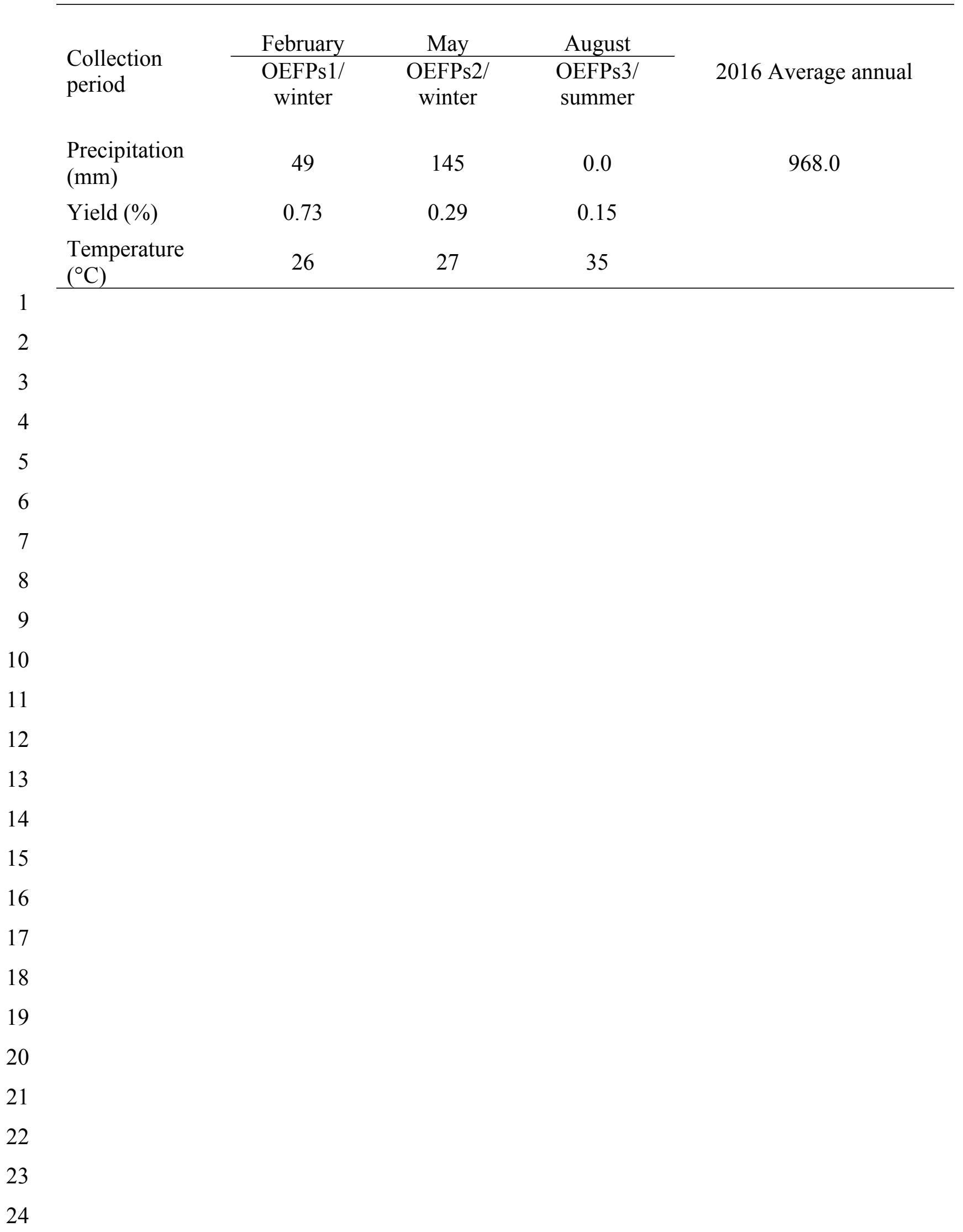




\section{Table 2 (on next page)}

Determination of the percentage composition of the chemical composition of the Psidium salutare leaf essential oil by Gas Chromatography coupled to Mass Spectrometry (CG/MS) in different collection periods.

$T R=$ Retention Time and OEFPs: essential oil from the leaves of Psidium salutare First collection (February), Second collection (May) e Third collection (August). Averages followed by different letters differ by Tukey test at $p<0.05$ 


\begin{tabular}{|c|c|c|c|c|c|}
\hline Compounds & $\begin{array}{c}\mathrm{tR}^{*} \\
(\mathrm{~min})\end{array}$ & OEFPs1 & OEFPs2 & OEFPs3 & $\%$ (media) \\
\hline 1,8 Cineole & 5.5 & $0.61^{\mathrm{a}}$ & $0.51^{\mathrm{a}}$ & $1.05^{\mathrm{a}}$ & 0.72 \\
\hline Dimethyl benzylcarbinyl acetate & 8.2 & $0.19^{\mathrm{a}}$ & $0.15^{\mathrm{a}}$ & $0.65^{\mathrm{a}}$ & 0.33 \\
\hline Copaene & 11.2 & $3.22^{\mathrm{a}}$ & $3.53^{\mathrm{a}}$ & $1.91^{\mathrm{a}}$ & 2.89 \\
\hline Cubenol & 14.8 & $0.63^{\mathrm{a}}$ & $0.0^{\mathrm{a}}$ & $3.42^{\mathrm{a}}$ & 1.35 \\
\hline Espatulenol & 12.2 & $0.23^{\mathrm{a}}$ & $0.30^{\mathrm{a}}$ & $0.13^{\mathrm{a}}$ & 0.22 \\
\hline Sabinene hydrate & 8.1 & $2.28^{\mathrm{a}}$ & $3.48^{\mathrm{a}}$ & $3.94^{\mathrm{a}}$ & 3.23 \\
\hline Isocarofilene & 11.9 & $3.78^{a}$ & $3.75^{\mathrm{a}}$ & $1.20^{\mathrm{a}}$ & 2.91 \\
\hline Limonene & 5.4 & $1.10^{\mathrm{a}}$ & $1.15^{\mathrm{a}}$ & $1.14^{\mathrm{a}}$ & 1.13 \\
\hline Linalool & 6.6 & $5.55^{\mathrm{a}}$ & $4.72^{a}$ & $7.26^{\mathrm{a}}$ & 5.84 \\
\hline Myrcene & 4.7 & $0.65^{\mathrm{a}}$ & $0.42^{\mathrm{a}}$ & $0.08^{b}$ & 0.38 \\
\hline Myrtenol & 7.5 & $0.21^{\mathrm{a}}$ & $0.16^{\mathrm{a}}$ & $0.09^{a}$ & 0.15 \\
\hline Ocimene & 5.7 & $2.15^{\mathrm{a}}$ & $1.93^{\mathrm{a}}$ & $1.50^{\mathrm{a}}$ & 1.86 \\
\hline Palustrol & 14.1 & $0.05^{\mathrm{a}}$ & $0.11^{\mathrm{a}}$ & $0.10^{\mathrm{a}}$ & 0.09 \\
\hline Patchoulane & 14.7 & $0.25^{\mathrm{a}}$ & $0.19^{a}$ & $3.08^{\mathrm{a}}$ & 1.17 \\
\hline P-Cymene & 5.3 & $5.05^{b}$ & $6.37^{b}$ & $17.83^{\mathrm{e}}$ & 9.75 \\
\hline Selina-3,7 (11) -diene & 13.6 & $0.37^{\mathrm{a}}$ & $0.28^{\mathrm{a}}$ & $0.0^{\mathrm{a}}$ & 0.22 \\
\hline Seychellene & 13.9 & $0.20^{\mathrm{a}}$ & $0.17^{\mathrm{a}}$ & $0.40^{\mathrm{a}}$ & 0.26 \\
\hline Terpineol & 8.3 & $1.67^{\mathrm{a}}$ & $0.90^{\mathrm{a}}$ & $0.12^{\mathrm{a}}$ & 0.90 \\
\hline Terpinolene & 6.4 & $16.99^{\mathrm{c}}$ & $14.49^{\mathrm{c}}$ & $6.90^{b}$ & 12.79 \\
\hline Valencene & 13.3 & $0.23^{\mathrm{a}}$ & $0.09^{a}$ & $0.30^{\mathrm{a}}$ & 0.21 \\
\hline Viridiflorene & 16.4 & $0.12^{\mathrm{a}}$ & $0.0^{\mathrm{a}}$ & $0.35^{\mathrm{a}}$ & 0.16 \\
\hline Viridiflorol & 14.7 & $0.53^{\mathrm{a}}$ & $0.95^{\mathrm{a}}$ & $2.07^{\mathrm{a}}$ & 1.18 \\
\hline$\alpha$-phellandrene & 5.0 & $0.15^{\mathrm{a}}$ & $0.08^{a}$ & $0.05^{\mathrm{a}}$ & 0.09 \\
\hline$\alpha$-caryophyllene & 12.4 & $0.24^{\mathrm{a}}$ & $0.29^{\mathrm{a}}$ & $1.68^{a}$ & 0.74 \\
\hline$\alpha$-cubebene & 15.0 & $0.90^{\mathrm{a}}$ & $2.05^{\mathrm{a}}$ & $0.0^{\mathrm{a}}$ & 0.98 \\
\hline
\end{tabular}




\begin{tabular}{|c|c|c|c|c|c|}
\hline$\alpha$-farnesene & 13.8 & $0.03^{\mathrm{a}}$ & $0.03^{\mathrm{a}}$ & $0.24^{\mathrm{a}}$ & 0.10 \\
\hline$\alpha$-gurjunene & 11.7 & $0.21^{\mathrm{a}}$ & $0.10^{\mathrm{a}}$ & $0.08^{\mathrm{a}}$ & 0.13 \\
\hline$\alpha$-muurolene & 12.6 & $0.63^{\mathrm{a}}$ & $0.72^{\mathrm{a}}$ & $0.69^{a}$ & 0.68 \\
\hline$\alpha$-pinene & 5.1 & $0.83^{\mathrm{a}}$ & $0.55^{\mathrm{a}}$ & $0.62^{\mathrm{a}}$ & 0.67 \\
\hline$\beta$-cadinene & 5.9 & $0.96^{\mathrm{a}}$ & $1.45^{\mathrm{a}}$ & $0.83^{\mathrm{a}}$ & 1.08 \\
\hline$\beta$-elemene & 13.7 & $0.16^{\mathrm{a}}$ & $0.12^{\mathrm{a}}$ & $0.70^{\mathrm{a}}$ & 0.33 \\
\hline$\beta$-eudesmene & 12.8 & $0.15^{\mathrm{a}}$ & $0.11^{\mathrm{a}}$ & $0.0^{\mathrm{a}}$ & 0.09 \\
\hline$\beta$-guaienum & 15.5 & $2.79^{a}$ & $3.12^{\mathrm{a}}$ & $0.0^{\mathrm{a}}$ & 1.97 \\
\hline$\gamma$-gurjunene & 13.6 & $0.10^{\mathrm{a}}$ & $0.21^{\mathrm{a}}$ & $0.26^{\mathrm{a}}$ & 0.19 \\
\hline$\gamma$-muurolene & 13.2 & $2.58^{\mathrm{a}}$ & $2.42^{\mathrm{a}}$ & $3.20^{\mathrm{a}}$ & 2.73 \\
\hline$\gamma$-terpinene & 5.9 & $13.97^{\mathrm{d}}$ & $17.09^{d}$ & $10.32^{c}$ & 13.79 \\
\hline$\delta$-cadinene & 13.3 & $5.27^{\mathrm{a}}$ & $3.88^{\mathrm{a}}$ & $3.84^{\mathrm{a}}$ & 4.33 \\
\hline$\delta$-cadinol & 15.3 & $1.68^{a}$ & $0.0^{\mathrm{a}}$ & $0.92^{\mathrm{a}}$ & 0.87 \\
\hline$\delta$-guaiene & 14.9 & $0.28^{a}$ & $0.28^{\mathrm{a}}$ & $3.70^{b}$ & 1.42 \\
\hline$\tau$-cadinol & 15.2 & $12.75^{\mathrm{d}}$ & $10.51^{\mathrm{d}}$ & $10.35^{\mathrm{d}}$ & 11.20 \\
\hline Monotherpenes hydrocarbons & & 40.06 & 41.53 & 37.82 & 39.79 \\
\hline Sesquiterpenes hydrocarbons & & 21.65 & 22.15 & 18.98 & 20.94 \\
\hline Oxygenated monotherpenes & & 11.15 & 10.32 & 13.08 & 12.98 \\
\hline Oxygenated sesquiterpenes & & 15.87 & 11.87 & 16.99 & 14.91 \\
\hline Others & & 1.01 & 0.79 & 4.13 & 1.44 \\
\hline Total & & 89.74 & 86.66 & 91.00 & 90.6 \\
\hline
\end{tabular}




\section{Table 3(on next page)}

The inhibitory effect of association the essential oil of Psidium salutare with fluconazole on Candida $(\mu \mathrm{g} / \mathrm{mL})$

OEFPs: Essential oil of Psidium salutare leaves, 1, 2 and 3 collections; CA: Candida albicans;

CT: Candida tropicalis; CK: Candida krusei; INCQS: National Institute of Health Quality Control. IC $\mathrm{C}_{50}(\mathrm{gg} / \mathrm{mL})$ : the inhibitor concentration that decreases $50 \%$ the of growth. 
1

\begin{tabular}{lcccccc}
\hline & \multicolumn{7}{c}{ Strains } \\
\cline { 2 - 7 } Tested Products & \multicolumn{7}{c}{ CA INCQS 40006 } & CT INCQS 40042 & CK INCQS 40095 \\
\cline { 2 - 7 } & CFM & $\mathrm{IC}_{50}$ & CFM & $\mathrm{IC}_{50}$ & CFM & $\mathrm{IC}_{50}$ \\
& $\mu \mathrm{g} / \mathrm{mL}$ & $\mu \mathrm{g} / \mathrm{mL}$ & $\mu \mathrm{g} / \mathrm{mL}$ & $\mu \mathrm{g} / \mathrm{mL}$ & $\mu \mathrm{g} / \mathrm{mL}$ & $\mu \mathrm{g} / \mathrm{mL}$ \\
\hline Fluconazole (FCZ) & 8192 & 16.8 & $\geq 16384$ & 9.3 & $\geq 16384$ & 271 \\
OEFPs 1+FCZ & 1024 & 2.7 & $\geq 16384$ & 2.6 & 8192 & 44.4 \\
OEFPs 2+FCZ & 8192 & 8.0 & $\geq 16384$ & 5.3 & 1024 & 32.4 \\
OEFPs 3+FCZ & 4096 & 6.3 & $\geq 16384$ & 3.7 & 8192 & 45.2 \\
\hline
\end{tabular}

2 


\section{Table 4 (on next page)}

The CFM $(\mu \mathrm{g} / \mathrm{mL})$ of the essential oil of Psidium salutare on different strains of Candida in modulatory effect.

OEFPs: Essential oil of Leaves of Psidium salutare, 1,2 and 3 collections; CA: Candida albicans; CT: Candida tropicalis; CK: Candida krusei; INCQS: National Institute of Quality Control in Health; 


\section{Tested Products}

\begin{tabular}{ccc|cc|cc}
\cline { 2 - 6 } Strains & $\begin{array}{c}\text { OEFPs1 } \\
\mu \mathrm{g} / \mathrm{mL}\end{array}$ & $\begin{array}{c}\text { OEFPs1+FCZ } \\
\mu \mathrm{g} / \mathrm{mL}\end{array}$ & $\begin{array}{c}\text { OEFPs2 } \\
\mu \mathrm{g} / \mathrm{mL}\end{array}$ & $\begin{array}{c}\text { OEFPs2+FCZ } \\
\mu \mathrm{g} / \mathrm{mL}\end{array}$ & $\begin{array}{c}\text { OEFPs3 } \\
\mu \mathrm{g} / \mathrm{mL}\end{array}$ & $\begin{array}{c}\text { OEFPs3+FCZ } \\
\mu \mathrm{g} / \mathrm{mL}\end{array}$ \\
\hline $\begin{array}{c}\mathrm{CA} \\
\mathrm{INCQS} \\
40006\end{array}$ & 1024 & 581.3 & 8192 & 1709.3 & 4096 & 1547.1 \\
\hline $\begin{array}{c}\mathrm{CT} \\
\mathrm{INCQS} \\
40042\end{array}$ & $\geq 16384$ & 2570.4 & $\geq 16384$ & 2754.2 & $\geq 16384$ & 1621.8 \\
\hline $\begin{array}{c}\mathrm{CK} \\
\mathrm{INCQS} \\
40095\end{array}$ & 8192 & 1621.8 & 1024 & 345.5 & 8192 & 1949.8 \\
\hline
\end{tabular}

2 


\section{Figure 1}

Cell viability curve and $\mathrm{IC}_{50}$ of the Psidium salutare essential oil (A, C and $\mathrm{E}$ ) and the oil in combined with fluconazole (B, D and F) against different Candida spp. strains, at different collection periods

Concentration of fluconazole: $2,048 \mu \mathrm{g} / \mathrm{mL}$. OEFPs: Essential oil of the leaves of Psidium salutare, 1, 2 and 3 collections; CA: Candida albicans; CT: Candida tropicalis; CK: Candida krusei; . INCQS- National Institute of Quality Control in Health. 
A)

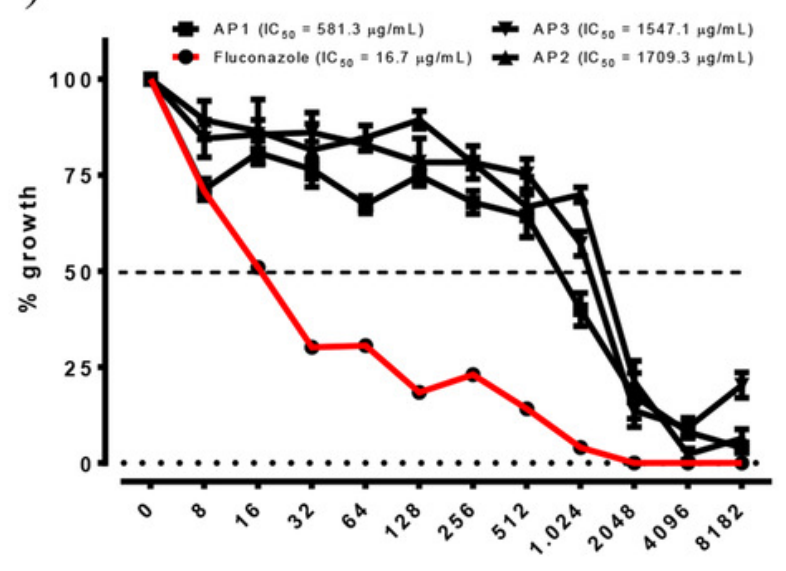

Concentration ( $/ \mathrm{g} / \mathrm{mL}$ L)

C)

CT INCQS 40042

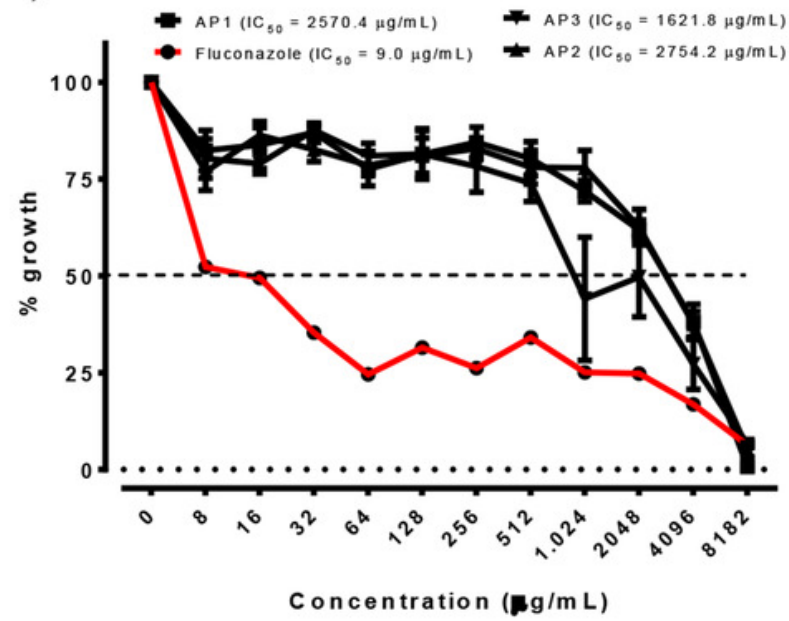

E)

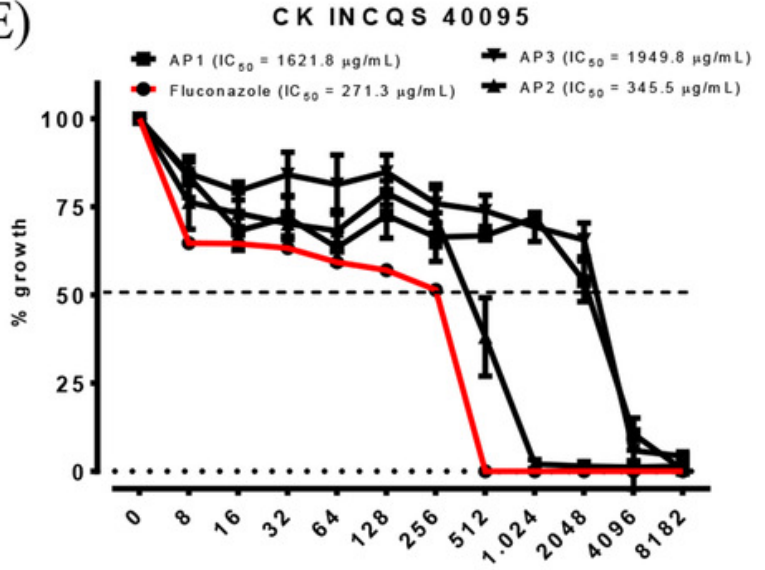

Concentration ( $/ \mathrm{g} / \mathrm{mL})$
B) $\quad C A$ INCQS 40006

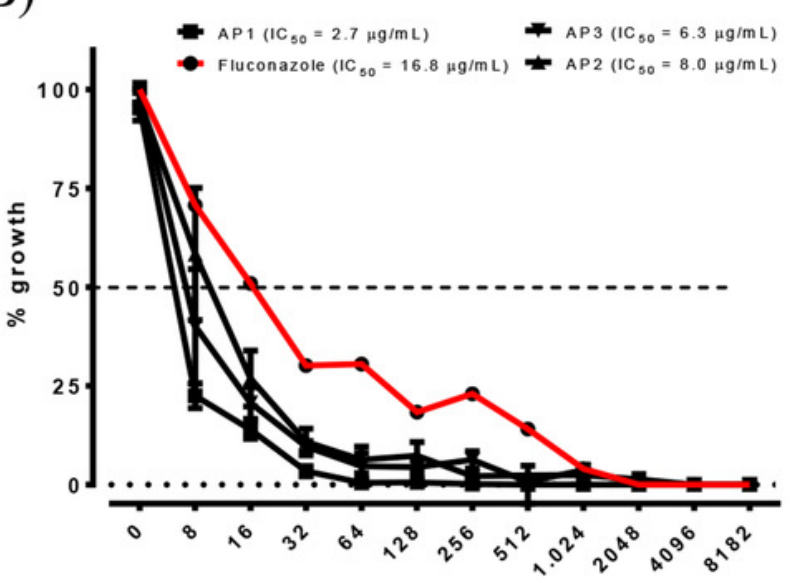

Concentration ( $/ \mathrm{g} / \mathrm{m} \mathrm{L})$

D)

CT INCQS 40042

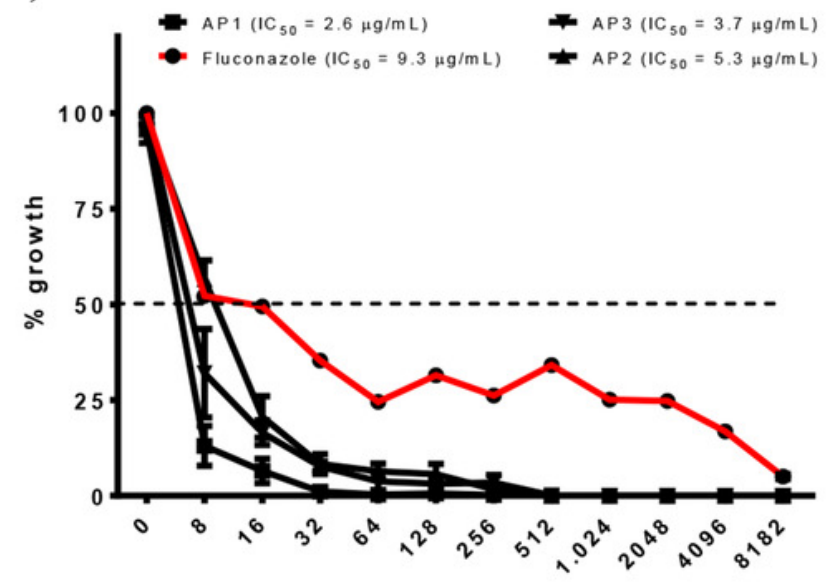

Concentration $(\mathbf{R g} / \mathrm{mL})$

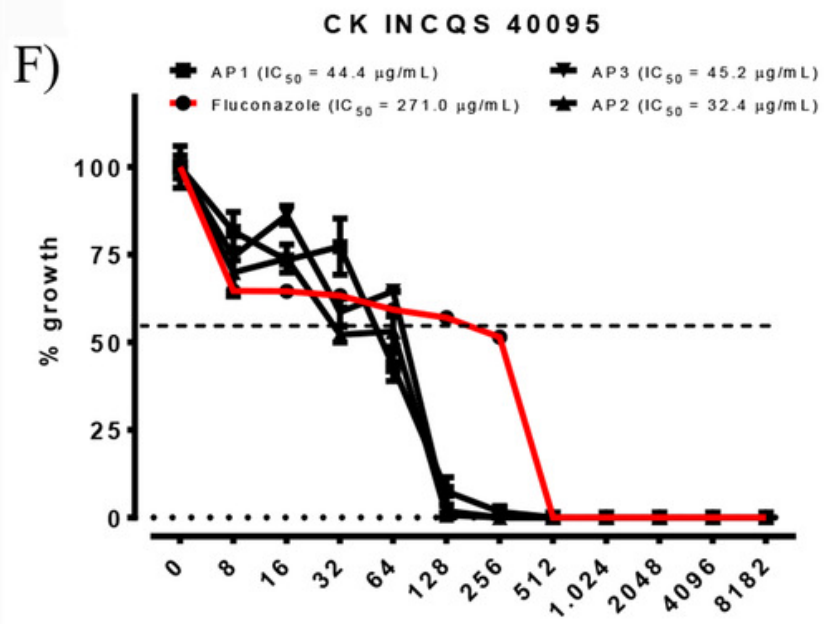

Concentration $(\mathbf{g g} / \mathrm{m} \mathrm{L})$ 


\section{Figure 2}

Effect of the Psidium salutare essential oil on Candida albicans yeast micromorphological aspects.

Culture performed in depleted Potato Dextrose Agar medium, with 40x objective visualization. (A) Growth Control, (B) Fluconazole Antifungal effect at 2,048 $\mu \mathrm{g} / \mathrm{mL}$, (C) Psidium salutare essential oil effect at 8,192 $\mu \mathrm{g} / \mathrm{mL}$, (D) Psidium salutare essential oil effect at 2,048 $\mu \mathrm{g} / \mathrm{mL}$ and (E) (C) Psidium salutare essential oil effect at $512 \mu \mathrm{g} / \mathrm{mL}$; CA: Candida albicans; INCQS: National Institute of Quality Control in Health.

*Note: Auto Gamma Correction was used for the image. This only affects the reviewing manuscript. See original source image if needed for review. 

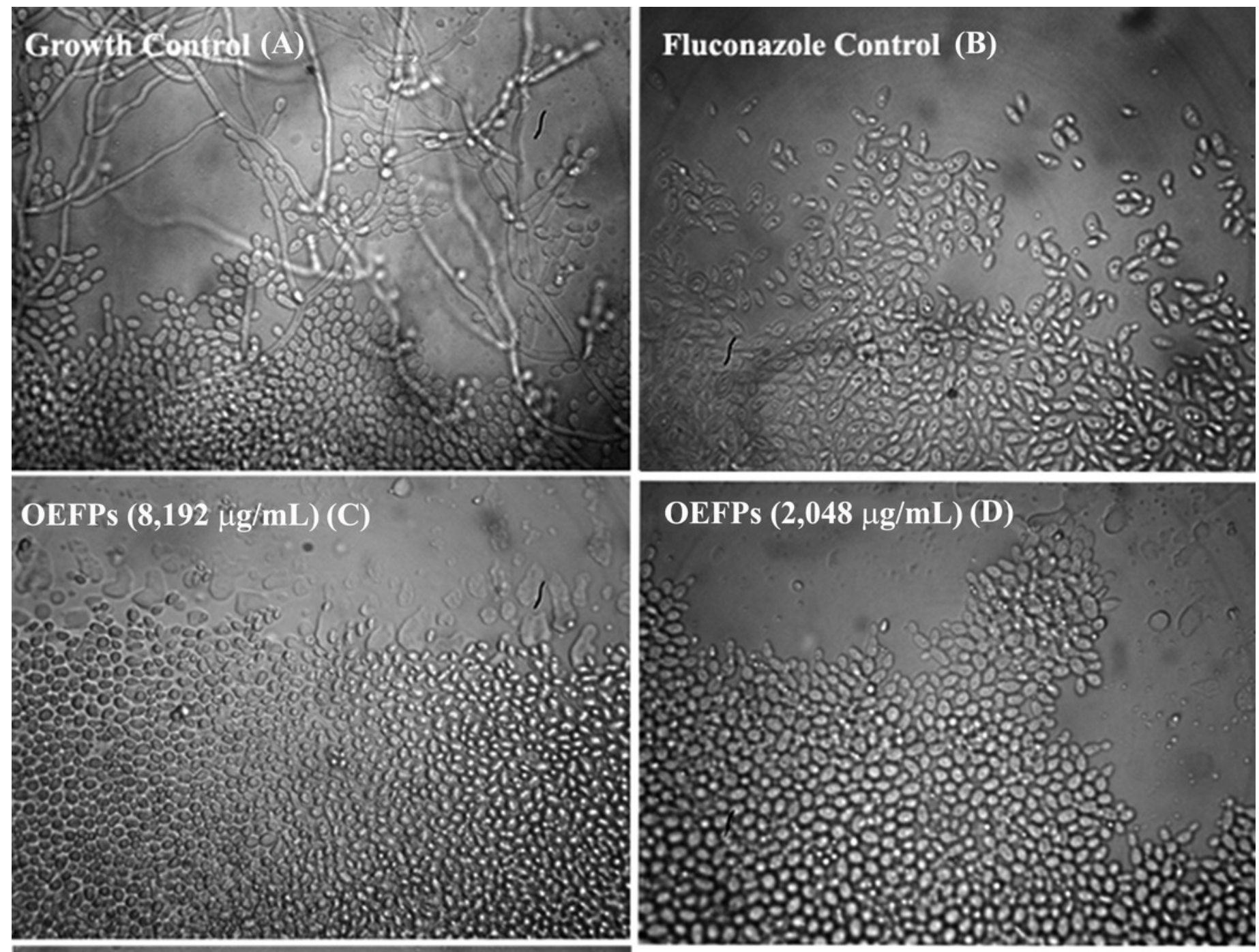

OEFPs $(512 \mu \mathrm{g} / \mathrm{mL})(\mathrm{E})$

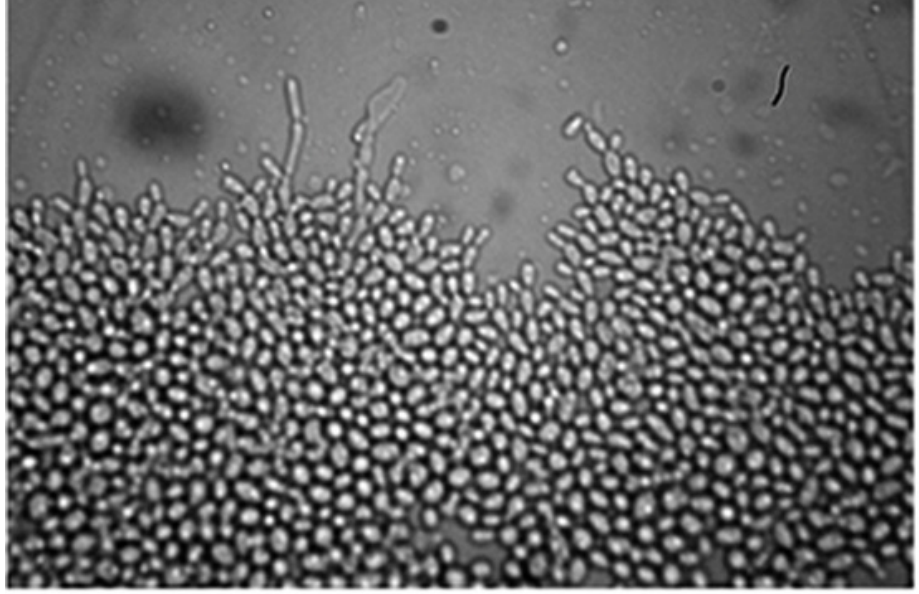

